\title{
CLIL in the Business English Classroom: From Language Learning to the Development of Professional Competence
}

\author{
Lihua Chen ${ }^{1, a}$ * \\ ${ }^{1}$ Department of foreign languages and affairs, Wuhan city vocational college, wuhan,430064,China \\ aemail: meredithshen@163.com
}

Keywords: CLIL; business english; professional competence

\begin{abstract}
The use of Content and Language Integrated Learning (CLIL) in language teaching at the higher education level has the potential to encourage learners to acquire language in an immersion-style setting. This paper presents a pedagogical intervention whereby 150 Business English (BE) students in their third year of a three-year study at a Chinese vocational institution were given a professional oral presentation based on peer collaborative work. This project was designed to heighten their level of enthusiasm for language learning, while stimulating risk-taking and ultimately boosting confidence-building. In the context of English for Specific Purposes (ESP) and more precisely, a course with a BE focus, this study aims to analyze if and how a CLIL-based approach can be implemented to teach a variety of professional skills, while assisting students in the development of their professional competence.
\end{abstract}

\section{Introduction}

Taking into account the current trends and concerns in teaching Business English, it's important to stress the following point: Business English is taught to a wide range of professional people and people in full-time education preparing for a business career. One of the questions which is often debated among the BE teachers is: "Are we teaching language or skills? "The use of Content and Language Integrated Learning (CLIL) in language teaching at the higher education level has the potential to encourage learners to acquire language in an immersion-style setting, since the integration of language and content provides a substantive basis for language teaching and learning. The content provides a motivational and cognitive foundation for language learning because it is of interest and value to the learner. In light of this, language learning by means of CLIL is not only active, but also passive, and in this setting, the focus is primarily on acquisition as opposed to intention. Students learn by doing and using language as a tool of communication and understanding. Hence, CLIL is also a means to assist in the development of analytic, reflective and hypothesizing skills. The real challenge is to keep students communicating and exchanging in the target language, while providing new information and methods to capture and keep their interest.

CLIL is a growing field in language teaching and basically means that the focus of courses is more on content than on language. The role of language is as a medium to convey the content. [1]We are already seeing something similar to this happening in business English training. How many of us teach pure language without some sort of content nowadays? We use the language to teach business skills such as telephoning, writing emails and giving presentations, as well as to practice soft skills such as communication strategies, dealing with conflict and effective team working, and of course to cover the vast area of intercultural competence. [2]In fact, some proponents of English may argue further that the language really is of little consequence compared to the content, i.e. getting the job done.

And in the field of English for Specific Purposes (ESP), we help our students to express themselves in business situations using vocabulary that they already know. The often bandied-about phrase "They know the content, we know the language" holds little water.[3] Our students do know the language; the job of today's ESP trainer is to help our students develop their business skills, soft skills and intercultural skills when using that language to communicate their message clearly and politely under international backgrounds. 


\section{CLIL, Project study and Business English}

What do teachers do if they have advanced language learners, who may have certain grammatical, lexical or pronunciation problems but for the most part are at ease in their L2. This is a problem we face constantly in our language classroom in a Chinese vocational institution, and we found that project studies provide the answer to the above dilemma. [4]The projet study method has been used in many fields in third level education and also lends itself nicely to language learning.[5] The next question may be where to find suitable project studies which are not too content-led and do not presuppose an in-depth knowledge of a specific subject matter. As the main aim of the language teacher is not to teach content but rather improve the student's communicative competence and oral proficiency in the L2, project studies written by language teachers and adapted to the language classroom are more appropriate than project studies written by business lecturers. [6]There are various publications on the market which respond to the language teachers' needs. While some books offer simulations with prescribed roles [7], others integrate mini-projects at the end of each chapter dealing with a specific topic such as international marketing or finance [8]. As far as interactive project studies go, two distinct types of project study can be identified: those that provide the learner with targeted content input to practise a specific skill such as negotiating, interviewing, problem-solving or decision-making and those which are more free to interpretation and call on the teacher to choose the preferred methodology and classroom strategy [9].

How can CLIL be applied as an effective teaching technique in business English classes? It includes practical material to use in class, which acts as a simulation of the business project and can be called a project, and the detailed information can be seen in table-1. Project studies are available to language learners and teachers and here a methodology is elaborated on how these project studies can be exploited to maximise student talking time in the language classroom. [10] Not all project studies are the same and with different levels of difficulty and skills trained, the choice of project study is tantamount to the success of your class. Project studies are extremely rich in content and can provide the learner with the potential to consolidate already acquired knowledge and train specific language and managerial skills. [11]Language teachers inexperienced in the use of the project study method may be inhibited by the content-based nature of the project study and therefore shy away from using project studies in class. This teaching methodology should help teachers plan their classroom to ensure effective execution of a project study.

Table 1. projects of business English learning

\begin{tabular}{|c|c|c|c|}
\hline Project & Periods & Content & Activities \\
\hline 1 & 6 & Interview & Simulation \\
\hline 2 & 6 & Business preparation & Role-play \\
\hline 3 & 6 & Business negotiation & Project study \\
\hline 4 & 6 & Business contract signing & simulation \\
\hline 5 & 6 & After-sale communication & Project study \\
\hline
\end{tabular}

\section{The Project Study Classroom}

During my teaching , I have divided this project section into three parts

1. Project Study Introduction - deals with the preparation of the project study, the introduction of a problem solving analysis and the pre-teaching of LSP (in this project, I use the example of meeting skills)

Project study class - here the class is divided into sections to include meetings, presentations of findings and discussion of recommendations.

Extended activities - the teacher gives feedback and comments on language mistakes, managerial skills and the presentation documents and support materials used with the help of the assessment table. The students reflect on the task-based study. 


\section{Project Study Introduction}

It is extremely important that the project studies are well prepared in advance so that each student knows what his role is. It is not sufficient just to give the project study to the student and hope that they will understand how to use it. This is the mistake made by many teachers unfamiliar with the project study method. There are many ways of introducing the project study to your students.

Here is a list of steps that should be completed during the project study introduction class.

1) Read the project of the project study thoroughly with your students. Here you can deal with any lexical or grammatical issues. You may also like to ask your students to represent the background information in a visual form. Use the blackboard or flipchart to get a clear picture of the company background. An example is shown in Figure 1. As you can see in this example, the main information is extracted from the project study, which will then be used later for further analysis.

2) Provide the students with some input on how they should analyse the project study. The problem solving analysis below is an example of how to get the students to analyse the project critically.

a) Read the project several times.

b) Define the main issues/problems.

c) Set out the firm's objectives.

d) Identify options open to the firm.

e) Draw up some criteria to evaluate the options chosen.

f) Select the best option.

g) Decide on how the option should be implemented.

h) Draw up an action plan to implement the solution chosen.

3) Pre-teach the language required to discuss the project study. There are many publications on the market for teaching meeting skills, presentation skills or negotiation skills. It is important to select the skill you would like to focus on and teach the specific language. If we take meetings as an example, we could do some of the following:

a)refer students to web sites to read up on the skill being practised. A web search will reveal any number of interesting sites.

b)If students have access to libraries, then they can read up on meeting skills in one of the many communication books on the market

c)brainstorm some key concepts of meetings such as type of meetings, people at a meeting, verbs, etc (see the worksheet in Appendix 1.)

d)move on to the language of meetings - provide the students with useful language input for both the chairperson and the participants such as the language of contradicting and disagreeing, interrupting, taking the floor etc.

f)familiarise the students with the documents of meeting - the form and content of agendas, minutes and memos. This should provide the student with more language input such as AOB, matters arising out of the last meeting, absentees, etc.

g)divide the class into small groups. You can either ask them to form the groups themselves or you can form the groups based on your class lists.

\section{Project Study Class}

Students should be divided into two small groups (maximum six students) to discuss different aspects of the same project study. Therefore, it is a good idea to find a project study that has two distinct parts. You must remind the students that they do not have all the information they need to solve the project but based on the information available, they can make recommendations and come to preliminary decisions. You can also inform your students that in real life situation in business, we do not have all the facts required to solve a problem.

In a one and a half hour session, the class time is divided into three half hour slots:

a)Meeting (30 minutes) - Groups (Group A and Group B) meet to discuss their part of the project study. 
b)Presentation (15 minutes per group) - Group A present their findings to the other group and vice versa.

c)Discussion (30 minutes) - all students come together to discuss the findings and make recommendations.

\section{Meeting (30 minutes)}

Students are divided into two groups (Group A and Group B) of four-six students to discuss their part of the project study. A chairperson is selected to lead the meeting and an agenda is drawn up. Students can be asked to prepare the agenda in advance and ensure everyone has a copy or they can write their agenda on the flipchart. Students discuss and provide recommendations, which they then represent graphically on transparencies or on the flipchart/chalkboard. You should impress on the students that their visuals should be clear, concise and coherent and long sentences are unacceptable. The students should then prepare their presentation. The facilitator should ensure that the chairperson does not monopolise the presentation but lets the other students have equal speaking time.

\section{Presentation (15 minutes per group)}

The findings of Group A are presented to Group B and vice versa. This should take approximately 15 minutes for each group including questions. Students must take detailed notes in order to participate actively in the third part of the lesson. Students will need to clarify the issues their group did not deal with by asking questions and repeating. This section should be treated as information exchange and the facilitator should prevent further discussion of the points presented. In order to include active participation of all students in this section, you could ask the students to share the presentation speaking time equally.

\section{Discussion (30 minutes)}

A discussion of both parts ensues whereby the students compare and contrast the various findings and suggestions made. Everyone should be encouraged to participate and a consensus should be reached on the main points raised in the presentation. This further elaboration of the items on the agenda will facilitate the writing of the detailed minutes, which should be prepared as homework.

Finally, the facilitator asks the students to prepare the minutes for the following week. The minutes are prepared in groups of three so that the students can consolidate their ideas on paper.

The transparencies and the agendas are collected by the facilitator for analysis and correction. Here is an example of extended activities from project 3.

\section{Name:}

\section{NEGOTIATION JOURNAL}

I learned:

$$
\text { Date: }
$$

I was surprised:

I will use this process again the next time I will:

One thing I learned about myself as a negotiator is:

One thing I learned about buyers and sellers is:

One thing I would like others to know about business negotiation is:

\section{Extended Activities}

All project study classes need to be assessed to include the language, the skills (in this project, meeting and presentation skills) and the support documents and written communication (the transparencies, the agenda and minutes). We will now look at these elements in more detail in table- 2 . Business English teaching can be very interesting and rewarding. Although it requires a variety of skills and techniques, it mostly boils down to good preparation and a professional approach, and it's more about helping learners develop their English skills for use in a business context. CLIL (Content and Language Integrated Learning) makes business English teaching promising, and some experts predict that it may replace pure language teaching at vocational institutions in the near future. 
Table 2. assessment form

\begin{tabular}{|c|c|c|c|}
\hline $\begin{array}{c}\text { Business } \\
\text { manners }\end{array}$ & $\begin{array}{c}\text { Language } \\
\text { competence }\end{array}$ & $\begin{array}{c}\text { Professional } \\
\text { competence }\end{array}$ & $\begin{array}{c}\text { Troubleshooting } \\
\text { skills }\end{array}$ \\
\hline $\begin{array}{c}\text { Interpersonal } \\
\text { ability }\end{array}$ & Confidence & $\begin{array}{c}\text { Attention } \\
\text { to details } \\
\text { score }\end{array}$ \\
\hline & & & \\
\hline
\end{tabular}

\section{References}

[1] Castler, K \& Palmer, D (1989). Business Assignments : Eight advanced project studies with video, Oxford University Press: Oxford.

[2] D., Falvey, D. \& Kent, S. (2000) Market Leader : Intermediate Business English, Longmann : Pearson Education Limited.

[3] D., Falvey, D. \& Kent, S. (2001) Market Leader :Upper-Intermediate Business English, Longmann : Pearson Education Limited.

[4] Crowther-Alwyn, J. (1997).Business Roles:12 Simulations for Business English, CUP: Cambridge.

[5] Crowther-Alwyn, J. (1999).Business Roles 2:12 Simulations for Business English, CUP: Cambridge.

[6] Gu Weiping, Section level, 2006, China's development direction ESP University Teaching [J], "foreign language"(4):36-40.

[7] Huang Ping, 2008, “Theory and Application of English for Specific Purposes”[M]. Chongqing:Chongqing University Press.

[8] Wu Cuihua, Training Course Reform of English to foreign trade ------ Business English Practical Project Analysis of teachers 'quality' of Shijiazhuang Vocational and Technical College "2009 (1): 75-77.

[9] Huang Yan, Improve the analysis and study of Business English teacher training capacity "Campus English", 2013 (16): 89-90.

[10] Julia M. Dobson, Effective Techniques For English Conversation Groups. USIA 3rd reprinting, Washington, D.C.1992.

[11] Kitty O’Locker, Business and Administrative Communication. 4th ed. Irwin McGraw-Hill 1998. 